\title{
WSPÓŁCZESNE MITY POLITYCZNE
}

\section{MITY OKRĄGŁEGO STOŁU ORAZ IV RZECZPOSPOLITEJ JAKO MITY POWSTANIA NOWEGO PAŃSTWA}

ABSTRACT Contemporary political myths. The Round Table myth and the Fourth Republic myth: myths of the creation of a new state

The concept of myth has been explored as a prelude to an analysis of the Round Table and the Fourth Republic of Poland, the political project which reached its peak in 2005-2007. Initially, the myths were designed to reduce the existential uncertainties and give meaning to human actions. Thus, in that sense, they were never false. This scheme has changed when political myth was born, which was purposely created in order to gain more power. The paper, by analyzing political speeches and some examples of election campaigns of 2005 and 2007, discusses the links between the irrational content of myth and the rational techniques used to spread it.

KEYWORDS Poland, myth, transformation, state, change

\section{WSTĘP}

Badania nad koncepcją mitu przedstawione w niniejszej pracy stanowią wstęp do analizy znaczenia dwumiesięcznych obrad okrągłego stołu z 1989 r. oraz IV Rzeczpospolitej, projektu politycznego, który swoje apogeum miał w latach 2005-2007. Początkowo mity miały zmniejszać wątpliwości natury egzystencjonalnej, wprowadzać ład i nadawać sens ludzkim poczynaniom, przez co nigdy nie były, co do istoty, fałszywe. Schemat ten uległ zmianie w chwili narodzenia się mitu politycznego, charakteryzującego się 
instrumentalnością, celowością tworzenia i świadomym jego wykorzystaniem dla pozyskania władzy. Teoretyczna, filozoficzna i socjotechniczna koncepcja współczesnego mitu politycznego została przeciwstawiona wizjom okrągłego stołu jako unikatowego na skalę światową sukcesu bądź miejsca zdrady ojczyzny, a także projektowi budowy IV Rzeczpospolitej. Analizując polityczne wypowiedzi oraz bazując na przykładach z kampanii wyborczych z 2005 i 2007 r., omówiono połączenie irracjonalności treści mitu z racjonalnymi technikami go organizującymi i uzasadniającymi.

Mity towarzyszą człowiekowi już od czasów powstania kultur pierwotnych. Ze względu na cechującą te ostatnie irracjonalność, ich występowanie było zjawiskiem powszechnym i niewątpliwie zrozumiałym. Dla człowieka żyjącego w świecie współczesnym, bogatszego od poprzednich pokoleń o całokształt dorobku cywilizacyjnego i naukowego, mit może brzmieć archaicznie, jako kategoria niemająca wpływu na jego życie. Jednak samo myślenie w ten sposób już jest mityczne, jako że mit istnieje i jest w kulturze wszechobecny. Ogół wiedzy i logicznych przesłanek, a także wiara w racjonalność paradoksalnie przysparzają mitom stabilności. Mit uspokaja, wyjaśnia i przedstawia proste rozwiązania, tak potrzebne w erze globalizacji i szumu informacyjnego. Oferuje gotowe recepty i zwalnia z myślenia, określając to, co dobre, tego, kto jest naszym sojusznikiem i ten cel, który jest słuszny. Dowodem tych twierdzeń jest przedstawiony w niniejszej pracy zrodzony po 2000 r. $^{1}$ mit narodzin IV Rzeczypospolitej. Owa koncepcja polityczna była postulowana przez prawicową partię Prawo i Sprawiedliwość (PiS) jako opozycja do „starego porządku”, III Rzeczpospolitej, która miała być centrum „zgnilizny” politycznej i moralnej. Formalne podstawy ukonstytuowania nowego państwa prezentował projekt konstytucji przygotowany przez PiS wiosną 2005 r. Jednak sam propagator, Paweł Szałamacha ${ }^{2}$, twierdzi, że idea ta była formułowana nie tyle w aktach prawnych, ile w sercach obywateli, dając nadzieję na odnowę życia publicznego ${ }^{3}$. Samo odwołanie do serca, czyli czynnika emocjonalnego, jest charakterystyczne dla mitu. Prześledzenie jego definicji, a także zapoznanie się z mitem politycznym i jego współczesną odmianą pozwoli ocenić zasadność formułowania mitu IV RP jako mitu powstania nowego państwa.

\section{MIT POLITYCZNY - PROBLEMY DEFINICYJNE}

Według Mircei Eliade, początkowo - w antyku - mythos było przeciwstawiane logos, jako to wszystko, co nie istnieje w rzeczywistości. Mit nadawał sens ludzkiej egzystencji i dostarczał gotowych wzorców zachowań ${ }^{4}$. Przede wszystkim miał jednak znamiona świętości, jako że opowiadał żywą i świętą historię na temat legendarnego początku

Sam termin został po raz pierwszy użyty już w 1998 r. przez politologa Rafała Matyję.

2 Paweł Szałamacha jest prawnikiem i byłym wiceministrem skarbu państwa w rządzie Prawa i Sprawiedliwości.

3 P. Szałamacha, IV Rzeczpospolita - pierwsza odstona. Dlaczego się nie udato, co trzeba zrobić, Poznań 2009, s. 14.

$4 \quad$ M. Eliade, Aspekty mity, przeł. P. Mrówczyński, Warszawa 1998, s. 8. 
i stworzenia świata przez „postacie nadnaturalne”. W tym znaczeniu nigdy nie był zatem fałszywy, ponieważ traktował o najbardziej odległych w czasie wydarzeniach rzeczywistych. Mit pozwalał zrozumieć, w jaki sposób powstał świat i kim są jego budowniczowie oraz uczynił zasadnym podporządkowanie się określonym regułom, nakazom i zakazom ${ }^{5}$, które Leszek Kołakowski nazywa „utratą wolności”. Wyznaczając gotową drogę i wzorce postaw, mit tworzy sztuczną barierę między nimi a innymi - tym samym odrzucanymi przez nas - wartościami, co pogłębia zniewolenie człowieka ${ }^{6}$. To cena, jaką człowiek płaci za poczucie ładu i schronienie w postaci gotowego wzoru wartości, niwelującego potrzebę jego intelektualnej oceny. Z kolei Bruno Schulz w krótkim eseju zatytułowanym Mityzacja rzeczywistości przekonuje, że wiedza nie jest niczym innym, jak budowaniem mitu o świecie, gdyż mit leży już w samych elementach i poza mit nie możemy w ogóle wyjść. [...] Duch ludzki niestrudzony jest w glosowaniu życia przy pomocy mitów, w „usensowianiu” rzeczywistości ${ }^{7}$. Mity mają zatem zredukować wątpliwości natury egzystencjonalnej, wprowadzić ład i nadać sens ludzkim poczynaniom.

Kategoria mitu politycznego nie odbiega w swej zasadniczej treści od pojęcia mitu. Jednak znaczące jest tutaj zawężenie rozważań nad jego przejawami do polityki. To ze względu na wyjątkowość tej sfery ewoluowała także funkcja mitu. Główny cel polityków, czyli pozyskanie władzy, powoduje świadome wykorzystywanie mitu jako środka do zwycięstwa. To za jego sprawą możliwe wydaje się manipulowanie zachowaniami i postawami politycznymi społeczeństwa. Mit ten korzysta z elementów wróżbiarstwa, które są przez graczy areny politycznej sprzedawane obywatelom jako filozofia czy czysta nauka. Bezkrytyczne przyjmowanie mitu wiąże się z wiarą w jego słuszność. Pewność polityków co do istnienia tej wiary pozwala na jego włączenie w ideologię i użycie przy tworzeniu obrządkowości politycznego życia społeczeństwa. Im bardziej system polityczny zmierza w kierunku autorytaryzmu i totalitaryzmu, tym więcej gotowych zhierarchizowanych norm, nakazów i zakazów wpaja się społeczeństwu8

O współczesnych mitach politycznych pisał już Ernst Cassirer w 1983 r. w dziele Mit pañstwa. Według niego cechują je instrumentalność, celowość tworzenia i świadome ich wykorzystanie przez zręcznych graczy jako środka do uzyskania określonej reakcji danych grup spolecznych (But here we find myth made according to the plan. The new political myth do not grow up freely [...]. They [myths - przyp. J.W.] are artificial things fabricated by very skilful and cunning artisans). Mit jako twór planowy może być zatem wytwarzany jak każda współczesna broń. Człowiek przeszedł ewolucję od homo magnus do homo faber ${ }^{9}$ i jako kreator może tworzyć polityczne mity z premedytacją $^{10}$. Przeciwstawienie homo magnus i homo faber wynika z faktu, że ten ostatni jest bogatszy o dorobek cywilizacyjny poprzednich epok - ma przyswojony sposób

Tamże, s. 11-14.

6 L. Kołakowski, The Presence of Myth, transl. A. Czerniawski, Chicago-London 1989, s. 19.

7 B. Schulz, Opowiadania; Wybór esejów i listów, oprac. J. Jarzębski, Wrocław 1989.

8 T. Biernat, Mit polityczny, Warszawa 1989, s. 306-308.

9 Określenie homo faber oznacza 'człowiek zręczny', 'twórca'.

10 E. Cassirer, The Myth of the State, Westport 1983, s. 277. 
postępowania i wzorce. Paradoksalność współczesnych mitów politycznych wynika zatem z połączenia irracjonalności ich treści i racjonalności technik organizujących je i uzasadniających. Zauważalna jest w tym przypadku także zmiana funkcji języka - słowa nie służą już do opisywania rzeczy i przestają być używane w tradycyjnym znaczeniu semantycznym. Mają oddziaływać na realne zjawiska i uzyskać nad nimi panowanie. Pożądany dla największej skuteczności mitu jest stan atomizacji, zaniku i rozpadu więzi nieformalnych ${ }^{11}$. Z kolei Raoul Girardet widzi w tych mitach przede wszystkim gotowy klucz, plan wyjaśniający rzeczywistość. Właściwe dla nich są płynność i niemożność ustalenia stałych granic - mity nakładają się i powielają same siebie. Ponadto, przez kult prawa i sprawiedliwości, wolności, solidarności oraz celebracji ojczyzny, przybierają kształt politycznej religijności. Od czasów sformułowania przez Cassirera i Girardeta tych poglądów upłynęło niemal trzydzieści lat. W dzisiejszej literaturze zauważa się także brak klarowności struktur i zwartego systemu wyobrażeń. Symbole i struktury nie są systemowo ujednolicone, a sam mit mówi wieloma głosami, czerpiąc z różnych źródeł ${ }^{12}$. Stabilność sytuacji gospodarczo-politycznej jest wykładnikiem poczucia bezpieczeństwa społeczeństwa, a przez to daje gwarancję stabilnych zachowań. Atrofia ładu i porządku społecznego powoduje, że działania zmierzające do wywołania u jednostek poczucia lęku i agresji stają się prostsze do wpojenia. Wzrasta wtedy potrzeba szybkich, prostych uzasadnień doznawanych niepowodzeń, co w polityce znajduje najczęściej wyraz w jednoznacznym wskazaniu winnego. Jako że ta sfera jest bardzo podatna na niestabilność, potrzeba wskazywania kozła ofiarnego jest znacznie wzmożona. W dodatku nieefektywność rządzących dotychczas praw zwiększa podatność na mit ${ }^{13}$. Historia ostatnich dwóch dekad polskiej sceny politycznej potwierdza tę tezę.

\section{MIT OKRĄGŁEGO STOŁU}

Mit okrągłego stołu swoją wyrazistość zawdzięcza temu, że przełom końca XX wieku w historii Polski wzbudza wiele emocji. Wysoki poziom skomplikowania sytuacji, która doprowadziła do upadku władzy komunistycznej, zrodził potrzebę narodzin mitu umożliwiającego przedstawienie prostego, gotowego wzorca zwalniającego ze żmudnego procesu zbierania i analizowania tekstów historycznych i źródłowych, a tym samym myślenia. Wywołana tym, w myśl Kołakowskiego, utrata wolności i stopniowe zniewolenie człowieka pozwoliły i pozwalają na manipulowanie potencjalnym elektoratem. W przypadku mitu okrągłego stołu jest on bardzo szeroki; nad wyraz ciekawe i charakterystyczne jest przenikanie się w jego ramach dwóch przeciwstawnych mitów - mitu wielkiego sukcesu oraz haniebnej zdrady i zaprzedania patriotycznych wartości. Oba pozwalają na wskazanie wielkich budowniczych wolnej Polski, którzy albo dopro-

\footnotetext{
11 M. Bal-Nowak, Mit jako forma symboliczna w ujęciu Ernsta A. Cassirera, Kraków 1996, s. 167.

12 K. Kowalski, Europa - mity, modele, symbole, Kraków 2002, s. 27.

13 M. Bal-Nowak, Mit jako forma..., s. 161-162.
} 
wadzili do bezkrwawego przełomu, przystępując do negocjacji, albo bronili i bronią prawdziwego wspólnego dobra i interesu Rzeczpospolitej, nie uczestnicząc w obradach - czy też sprzeciwiając się im lub ich rezultatowi. Wybór jednego modelu i dalsze jego powielanie zależy zatem od politycznej strategii aktorów sceny politycznej. Nie oznacza to jednak, że wykorzystanie tego mitu w podobny sposób musi prowadzić do nieformalnych porozumień bądź koalicji, gdyż mit raz utworzony może być dowolnie wykorzystywany przez poszczególne zainteresowane jednostki.

Wizję okrągłego stołu jako wielkiego sukcesu można dostrzec w sformułowaniach Adama Michnika, który zachęca do postrzegania rozmów prowadzonych od 6 lutego do 5 kwietnia 1989 r. jako najbardziej romantycznej operacji politycznej w polskiej historii XX wieku ${ }^{14}$. Stwierdzając także: Gdy po śmierci pójdę na Sąd Ostateczny, św. Piotr spyta mnie: - Co dobrego, synu, zrobiteś? A ja odpowiem: - Mojego synka Antosia i Okragty Stót ${ }^{15}$, Michnik odwołuje się do miłości rodzicielskiej, jednego z najwyższych uczuć ludzkich, nadając obradom niemal sakralny wymiar. Niemniej jednak negocjacje z częścią opozycji solidarnościowej były prowadzone już przed lutym 1989 r. i stanowiły podstawę do samej akceptacji pomysłu przystąpienia do wspólnych obrad (już miesiąc wcześniej ekipa Wojciecha Jaruzelskiego wyraziła zgodę na legalizację „Solidarności”, a do pierwszego spotkania Lecha Wałęsy z Czesławem Kiszczakiem doszło w sierpniu 1988 r.). Gospodarcze procesy liberalizacyjne również zostały zapoczątkowane wcześniej. Już 23 grudnia 1988 r. Sejm przyjął ustawy o podejmowaniu dziatalności gospodarczej oraz o dziatalności gospodarczej z udziatem podmiotów zagranicznych, a przed zakończeniem rozmów przy okrągłym stole, 15 marca 1989 r., zalegalizowano obrót obcymi walutami ${ }^{16}$. Fakty te przysłonił mit sukcesu okrągłego stołu poparty mitem samej „Solidarności”. Idealizacji ruchu w społeczeństwie sprzyjały odwołania historyczne, wzbudzające silne emocje. Dzięki wpisaniu ruchu w historię powstań narodowych bądź Insurekcji Kościuszkowskiej ${ }^{17}$ „Solidarność" jawiła się jako przejaw wizji długo obecnej w historii Polski. $Z$ tego też względu postulaty ruchu postrzegano jako odpowiedź na uniwersalne problemy, a ich realizacja mogła doprowadzić do ostatecznych rozwiązań długotrwałych przeciwności. Pierwszym etapem prowadzącym do „odczarowania” tak rozumianej polityki „Solidarności” był jednak sam okrągły stól, który pokazał, jak iluzoryczna jest wiara w realizację polityki „Solidarności” bez negocjacji ze stroną rządzącą oraz koniecznych ustępstw na jej rzecz.

Romantyczny mit okrągłego stołu jako powstania nowego państwa potęgowało uznawanie tej formy transformacji ustrojowej za zjawisko unikatowe, przypisywane wyłącznie stronie polskiej. Jak stwierdził Władysław Frasyniuk podczas konferencji z okazji 20-lecia obrad: Okragty stót to polski fenomen, który podziwiany jest na catym

14 To sięwpale nie mieścito, wżadnejpale, Interia.pl, 5 II 2009, [online] http://fakty.interia.pl/raport/20-lat-okraglego-stolu/news/to-sie-w-pale-nie-miescilo-w-zadnej-pale,1254878, 20 XII 2011.

15 A. Kubnik, M. Olejnik, Rachunek win, „Gazeta Wyborcza”, 3 II 2001, s. 6.

16 A. Dudek, Historia polityczna Polski 1989-2005, Kraków 2007, s. 21-27.

17 M. Frybes, P. Michel, Po komunizmie. O mitach w Polsce wspótczesnej. Wstęp, [w:] Wielka transformacja. Zmiany ustroju w Polsce po 1989, red. I. Krzemiński, Warszawa 2011, s. 32. 
świecie $^{18}$. Należy jednak zauważyć, że państwa satelickie Związku Radzieckiego stanowiły ostatni krąg państw, które - w liczbie ok. 30 - były poddane tzw. trzeciej fali demokratyzacji ${ }^{19}$. Według Samuela Huntingtona systemy autorytarne bądź totalitarne zostały zastąpione demokratycznymi najpierw w Europie Południowej (za początek uznał on wydarzenia w Portugalii z 1974 r.), następnie w Ameryce Łacińskiej oraz Azji; dopiero później proces ten dotarł do Europy Wschodniej. Ponadto punktem wspólnym genezy rewolucji na terenie tego ostatniego obszaru jest zmiana geopolityczna, tzn. reorientacja polityki ZSRR wobec swoich satelit. Bez tak radykalnej zmiany, zewnętrznej w stosunku do władzy oraz opozycji, transformacja ustrojowa byłaby nieprawdopodobna ${ }^{20}$.

Odmienny sposób przedstawiania obrad okrągłego stołu, jako zdrady ojczyzny i spisku, pozwala na ukazanie opinii publicznej w złym świetle oraz osłabienie wielu przeciwników politycznych przez osoby, które w tych negocjacjach nie brały udziału. Jeszcze 16 lat później Janusz Korwin-Mikke w artykule opublikowanym przez tygodnik „Najwyższy Czas!” przekonywał, że ludzie p. Generata [Jaruzelskiego - przyp. J.W.] zasiedli przy stole dla odegrania bardzo tadnej komedii pt. „Budujemy Demokrację". Wybudowali sobie PRL-bis, zwiększając liczbę partyj politycznych - i jednocześnie (czterokrotnie) liczbę posad, by partyjniacy z tych partyj mieli na czym sięposadowić... I taka jest rzeczywistośc III RP. Pisał także: „[...] co to jest „zasiedli z NAMI”? [do negocjacji przy okrągłym stole - przyp. J.W.] Z jakimi „nami”? Zasiedli ze swoimi agentami troskliwie wybranymi przezp. gen. Czestawa Kiszczaka - oraz z reprezentantami eurolewicy, żydokomuny i czego tam jeszcze chcieć. [...] Ani Adam Michnik, ani p. Lech Watęsa MNIE nie reprezentowali!!!?2. W tych wypowiedziach mit pełni funkcję wyjaśniającą, ukazującą uproszczony, zrozumiały dla każdej grupy społecznej model rzeczywistości. Spotęgowany został silnym ładunkiem emocjonalnym oraz mitotwórczą rolą słów, pozwalającą na stworzenie kontrastu my-oni, który implikuje istnienia tylko wrogów i sojuszników, bezsprzecznego dobra i zła. Mimo upływu wielu lat mit ten jest wciąż podtrzymywany, jako że wielu uczestników obrad z 1989 r. wciąż jest aktywnych na scenie politycznej. W 2010 r., w 30. rocznicę podpisania Porozumień Sierpniowych, Marian Jurczyk, pierwszy przewodniczący „Solidarności '80” stwierdził: W ciagu 30 lat Polska odeszta od ideatów Sierpnia, a po okragtym stole wszystko idzie w ztym kierunku $u^{22}$. Należy przypomnieć, że w wyniku negocjacji przy okrąglym stole uzgodnio-

18 Konferencja: Okragty Stót to fenomen w skali światowej, PAP, 6 II 2009, [online] http://www.naukawpolsce.pap.pl/aktualnosci/news,358804,konferencja-okragly-stol-to-fenomen-w-skali-swiatowej. html, 1 VI 2012.

19 S. Huntington, Trzecia fala demokratyzacji, przeł. A. Dziurdzik, Warszawa 1995, s. 9.

20 J. Chodak, Zostaty „zrobione” czy nadeszty? Transformacje polityczne roku 1989 w Europie Wschodniej wperspektywie teorii rewolucji, [w:] Okragty Stót - dwadzieścia lat później. Zbiór studiów, red. W. Polak $\mathrm{i}$ in., Toruń 2009, s. 115.

21 J. Korwin-Mikke, Okragty Stót, „Najwyższy Czas!”, 1 I 2005, [online] http://korwin-mikke.pl/najwyzszy_czas/zobacz/bdquookragly_stolrdquo/240, 1 VI 2012.

22 Pod bramą stoczni. Jurczyk: Wszystko idzie źle, Gazeta.pl, 30 VIII 2010, [online] http://szczecin.gazeta.pl/szczecin/1,34939,8315367,Pod_brama_stoczni_Jurczyk_Wszystko_idzie_zle.html, 1 VI 2012 . 
no, że związek zawodowy „Solidarność” zostanie zalegalizowany, ale podpisano także aneks, na mocy którego zawieszeniu uległy te artykuły, które stały w sprzeczności z ustawą o związkach zawodowych z 1982 r. (w tym prawo do strajku). Ten stan rzeczy był nie do zaakceptowania dla części działaczy „Solidarności”, z Marianem Jurczykiem na czele, którzy z tego między innymi względu zadecydowali o założeniu konkurencyjnej „Solidarności ' 80 ”23. Wyraźne podkreślenie cezury czasowej w postaci obrad okrągłego stołu jako momentu schyłku wartości ma zdyskredytować dorobek osób go tworzących. Z kolei Antoni Macierewicz w 2009 r. w Pałacu Prezydenckim stwierdził, że okrągły stół był jedynie zdradą, a negocjacje prowadzone w jego ramach porównał do rozmów przeprowadzonych w Milanówku w 1945 r., zakończonych aresztowaniem przez NKWD przywódców Polskiego Państwa Podziemnego ${ }^{24}$. Odwołanie do II wojny światowej nadaje tym słowom funkcję mitotwórczą. Przywołując skojarzenie z największą zbrodnią i stawiając Polskę oraz Polaków w roli bezbronnej ofiary, pozwala na nadanie magicznego znaczenia obradom z $1989 \mathrm{r}$. Nie bez wpływu pozostaje także czas, w którym padały powyższe wypowiedzi. Sam mit pojawia się w sytuacjach krytycznych; za taką można uznać kryzys finansowy prowadzący do zmiany nastrojów społecznych. W takim okresie rośnie niezadowolenie opinii publicznej poszukującej prostych rozwiązań problemów, a przede wszystkim winnego zaistniałej sytuacji. Zwiększona podatność na mit pozwala na szybsze jego wykorzystanie do własnych, politycznych celów, co zauważalne jest np. w poniższej wypowiedzi Macierewicza z 2009 r.: Okragty Stót nie stat się droga do niepodlegtości, byt sposobem na przeprowadzenie Polski z podlegtości sowieckiej do podlegtości neosocjalistycznej Unii Europejskiej. Gdyby nie paktowano z komunistami, Polska bytaby dziś silnym i bogatym państwem, a nie petentem $w$ przedpokoju niemieckim ${ }^{25}$. Problemy gospodarcze kraju oraz jego pozycja na arenie międzynarodowej zostały tutaj uproszczone jedynie do skutków decyzji podjętych w $1989 \mathrm{r}$.

W tym miejscu nie sposób nie odwołać się do wypowiedzi premiera Donalda Tuska, który w jednym ze swoich przemówień wskazał na inny mit założycielski III Rzeczpospolitej. W kwietniu 2010 r., podczas obchodów 70. rocznicy zbrodni katyńskiej, stwierdził on: [...] Katyń stat się w najgtębszym tego stowa znaczeniu mitem. Miat być ktamliwym mitem zatożycielskim państwa komunistycznego, ale ci, którzy na tym ktamstwie chcieli ufundować powojenna Polskę, przegrali z prawdą, bo narodzit się mit powtarzany z ust do ust przez cate pokolenia. Zawsze wtedy, gdy mówiono nawet szeptem prawdę o Katyniu, wiedzieliśsmy, że nas nie pokonali. Prawda o Katyniu stata się mitem zatożycielskim niepodlegtej Polski ${ }^{26}$. Walka z komunistyczną propagandą została uznana za symbol rodzącej się suwerennej Polski. Świadomość prawdy historycznej

23 A. Dudek, Historia polityczna Polski..., s. 24.

24 J. Sanecka, K. Trembicka, Okragty Stót w Polsce - Mity istereotypy w dwadzieścia lat później, [w] Okragty Stót..., s. 480.

25 Tamże, s. 481.

26 Tusk: Ofiary Katynia czekają, by przemoc i ktamstwo zmienić w pojednanie, Gazeta.pl Wiadomości, 7 IV 2010, [online] http://wiadomosci.gazeta.pl/wiadomosci/1,114873,7741000,Tusk_Ofiary_ Katynia_czekaja_by_przemoc_i_klamstwo.html, 1 VI 2012. 
i krzewienie jej wśród współobywateli pozwoliło na wykształcenie się w społeczeństwie poczucia wyzwolenia i wyodrębnienia swoistej strefy wolności od partyjnego zakłamania. I choć obecnie podstawowe fakty co do wydarzeń z 1940 r. pozostają w opinii historyków bezsprzeczne, samą „prawdę o Katyniu” można interpretować na wiele sposobów, co rodzi podstawy do ewolucji raz utworzonego mitu i wykorzystania go we współczesnej walce politycznej.

Wynika to z faktu, że cechą charakterystyczną współczesnych mitów politycznych jest ich wzajemne przenikanie się, co można zauważyć zarówno w przypadku mitu okrągłego stołu, jak i mitu IV Rzeczpospolitej.

\section{MIT IV RZECZPOSPOLITEJ}

Potrzeba zbudowania nowej, IV RP wyrosła z braku skuteczności modelu władzy przyjętego przez Sojusz Lewicy Demokratycznej w wyborach z 2001 r. Ostatnie lata ich rządów obfitowały w skandale i afery ${ }^{27}$ ukazujące wszechogarniającą korupcję elity politycznej i jej nieudolność. To głównie na bazie przeciwstawienia III RP przyszłej IV RP opierała się kampania wyborcza Prawa i Sprawiedliwości z 2005 i 2007 r. IV RP stanowiła klucz i odpowiedź na problemy zmęczonego politycznymi kłamstwami społeczeństwa. Mit ten przedstawiał prosty model złego i dobrego, czarnego i białego, bez potrzeby intelektualnego wysiłku w doszukiwaniu się wartości pośrednich. Cała III RP została potraktowana jako przejaw zła i „zgnilizny” moralnej, jako państwo, które byto do tej pory jakimś gigantycznym skandalem, byto takim, powiedzmy sobie, takim postkolonialnym, miękim two$\mathrm{rem}^{28}$. Tylko zakopanie jej zgliszcz i całkowita zmiana politycznego kursu miała umożliwić odbudowę moralną i poprawę kondycji państwa polskiego. Prawo i Sprawiedliwość samowolnie przyznało sobie monopol na ratunek Polaków z tej sytuacji, podkreślając, że nie ma żadnego innego wariantu (i opcji politycznej), który wyprowadziłby obywateli ze świata cienia. Jeszcze w 2007 r. Jarosław Kaczyński przekonywał, że taki jest realny wybór [między IV a III Rzeczpospolitą - przyp. J.W.] w Polsce. Każdy, kto sądzi, że jest inaczej, żyje w btędzie. Odsunięcie PiS-u od wtadzy oznacza powrót Rywinlandu².

Charakterystyczna dla współczesnego mitu funkcja wyjaśniająca znajduje na arenie politycznej doskonałe pole do popisu w postaci haseł wyborczych i sloganów. W kampanii z 2005 r. przeciwko Platformie Obywatelskiej PiS stworzył podział na „Polskę solidarną” i „Polskę liberalną”. Oczywiście wydaje się on mieć rację bytu ze względu na rozbieżności programu ekonomicznego dwóch partii, jednak PiS rozbudował pojęcie „liberalizmu” w taki sposób, by nadać mu sens jak najbardziej pejoratywny. To wypaczenie pojęcia i manipulowanie znaczeniem słowa jest rozpoznawalne jako cecha zna-

27 Jako przykłady można podać afery starachowicką i orlenowską, aferę Pęczak-Dochnal czy nieprawidłowości przy prywatyzacji PZU.

28 Sygnaty dnia, „Program Pierwszy Polskiego Radia”, 3 IV 2007, [online] http://www.polskieradio.pl/ jedynka/sygnalydnia/artykul9967.html, 20 XII 2011.

29 Sygnaty dnia, „Program Pierwszy Polskiego Radia”, 10 VII 2007, [online] http://www.polskieradio. $\mathrm{pl} /$ jedynka/sygnalydnia/artykul10167.html, 20 XII 2011. 
mienna mitu. Przykładem może być wypowiedź Jarosława Kaczyńskiego dla „Naszego Dziennika”: Nasza wierność idei Polski solidarnej jest poza wszelka dyskusją. [...] Stanowczo odrzucamy też wynaturzenia liberalizmu przejawiajace się brakiem szacunku dla ludzkiego życia od samego poczęcia, lekceważeniem macierzyństwa i rodziny, apoteoza obyczajowej rozwiaztości, ustawowym promowaniem beznadziejnych „związów partnerskich”.

Jak widać, żaden z przytoczonych przykładów nie odnosi się do zagadnień związanych z ekonomią. Różnice w podejściu do roli państwa w gospodarce PO i PiS-u są niebagatelne i stanowią podstawę do publicznej debaty. Nie zmienia to jednak faktu, że duża część społeczeństwa nie miała nigdy do czynienia z ekonomią jako nauką, nie rozumie różnic między zwiększonym liberalizmem a interwencjonizmem państwowym lub też nie ma chęci przeglądać programów wyborczych, by odnaleźć te różnice. Dlatego prostszą metodą było wykorzystanie mitu nacechowanego ładunkiem emocjonalnym. W cytowanej wyżej wypowiedzi liberalizm został uproszczony do tych wszystkich norm i zasad obyczajowych, które mają być odbierane jako złe. Odwołania te miały nawiązywać nie do gospodarki, a do ideologii liberalizmu, głoszącego prymat wolności i przypisującego wyższą rolę indywidualizmowi niż wspólnocie. Tutaj dana doktryna został uproszczona tylko do jej wynaturzeń. Tkwił w tym miało ukryty cel: miało to przekonać opinię publiczną do utożsamiania liberalizmu z jego wynaturzeniami. Potwierdza się zatem pogląd Cassirera na współczesny użytek z mitu, który jest bogaty w irracjonalną treść, ale charakteryzuje się racjonalną techniką jego kreowania.

Innym przejawem funkcji wyjaśniającej mitu IV RP jest usytuowanie sytuacji państwa polskiego w analogicznej sytuacji do II RP. Taki zabieg jest szybkim i prostym rozwiązaniem - obywatele nie muszą trudzić się nad nadawaniem sensu rzeczywistości czy ubolewać nad niewiadomymi, przez którymi stoi ich kraj. Polska stanęła w tej samej sytuacji co II RP, zatem najlepszym wyjściem będzie sięgnięcie do rozwiązań historycznych, tych samych, które już się sprawdzity: Pamiętamy, że w 1921 r. zostata uchwalona lewicowa, wyzbyta podtoża aksjologicznego konstytucja, która bardzo szybko obnażyta choroby panstwa polskiego. W 1935 r. zostata ona zastąiona przez konstytucje kwietniowa, porzadkujaca kwestie ustrojowe i dajaca podstawy do naprawy państwa. Konstytucja sanacyjna, choć w niepodlegtej Polsce funkcjonowata tylko 4 lata, zapewnita ciagtość ustrojowa naszego pañstwa po utracie niepodlegtości w wyniku agresji hitlerowskiej i w czasach zniewolenia Narodu w Polsce Ludowej, która nie otrzymata miana III Rzeczypospolitej ${ }^{30}$. Oprócz prostej analogii do naprawy państwa przez wyzwoliciela - marszałka Piłsudskiego, którym w obecnych czasach ma być PiS - w tym nawiązaniu historycznym można dostrzec jedną z socjotechnik wyborczych, tj. irradiację. Odwołuje się ona do koncepcji przepływu autorytetu: gdy stosunek emocjonalny do danej postaci jest dodatni, istnieje duże prawdopodobieństwo, że zostanie on przeniesiony na osobę, która z autorytetu owej postaci korzysta ${ }^{31}$. Szacunek, jakim w polskim społe-

30 A. Górski, Jaka IV Rzeczpospolita?, Wywiad przeprowadzony na terenie Parafii Rzymsko-Katolickiej Narodzenia NMP na Płudach, 5 VII 2006, [online] http://www.pis.org.pl/article.php?id=4569, 1 VI 2012.

31 P. Pawełczyk, D. Piontek, Mity i stereotypy w socjotechnikach wyborczych, [w:] W kregu mitów i stereotypów, red. K. Borowczyk, P. Pawełczyk, Poznań-Toruń 1993, s. 46-47. 
czeństwie wciąż cieszy się Marszałek, odzwierciedlają badania przeprowadzone w 70 . rocznicę jego śmierci (w 2005 r., czyli roku wyborów parlamentarnych i prezydenckich) przez stację telewizyjną TVN za pośrednictwem Pracowni Badań Społecznych. Ankietowani wymienili Józefa Piłsudskiego jako drugiego (po papieżu Janie Pawle II) najważniejszego Polaka XX wieku. Z kolei na pytanie: Czy pojawienie się obecnie w polskiej polityce postaci takiej jak marszatek Józef Pitsudski bytoby dobre, czy też niedobre dla Polski? - 63,5\% badanych odpowiedziało, że byłoby dobre (w tym $28,1 \%$ - zdecydowanie dobre), a tylko $17,4 \%$, że byłoby niedobre (w tym 3,4\% - zdecydowanie niedobre $)^{32}$. Świadomość respektu, jakim Polacy darzą Józefa Piłsudskiego wpłynęła na częste powracanie przez polityków partii do analogii między II a IV RP, a także przedstawianie IV RP jako kontynuatorki dzieła II RP - jako że odpowiednikiem konstytucji sanacyjnej miał być projekt nowej konstytucji przygotowanej przez $\mathrm{PiS}^{33}$.

Ciekawie przedstawia się zestawienie koncepcji Girardeta z mitem IV RP. Girardet rozpatrywał współczesne mity polityczne jako przejaw politycznej religijności. Jednak specyfika sceny politycznej Polski wynika w dużej mierze z chrześcijańskiej tradycji państwa polskiego, wysokiej pozycji Kościoła katolickiego i częstego odnoszenia się do religijnych wartości moralnych w dyskursie społecznym. To właśnie Kościół, a dokładniej Kościół toruński ${ }^{34}$, stał się dla PiS-u przepustką do zdobycia władzy w 2005 r. Mocne osadzenie religii w państwie nie wymusza zastępowania jej katalogiem praw, co pozornie dyskwalifikuje myśl Girardeta w analizowanym przypadku. Wymienione przez niego elementy politycznej religijności (kult prawa, sprawiedliwości, wolności, solidarność i celebracja ojczyzny) doskonale jednak pasują do wizerunku PiS-u kreowanego przez samych działaczy partii. Najwyższa ranga prawa i sprawiedliwości jest widoczna w samej nazwie ugrupowania - nazwanie się prawym i sprawiedliwym sugeruje mityczny wydźwięk partii. Ponadto waga norm prawnych i obowiązek ich przestrzegania zostały zaakcentowane w haśle wyborczym zlikwidujemy korupcję. Z kolei odniesienie do takiej wartości, jak solidarność, wykorzystano w spocie reklamowym Patriotyzm, solidarność, nowoczesnos ${ }^{35}$ i przede wszystkim w głównym haśle Polska solidarna. Celebracja ojczyzny była widoczna w deklaracjach rządu (2005-2007) na temat prowadzenia świadomej polityki historycznej. PiS i LPR (ówczesny koalicjant PiS-u) były zwolennikami wprowadzenia lekcji wychowania patriotycznego. Dodatkowo sam Jarosław Kaczyński w wywiadzie dla Telewizji Trwam stwierdził: Chcemy pokazać, że IV Rzeczpospolita ma poparcie. Że Polska uczciwa, Polska opierajaca się o swoje historyczne korzenie, oczywiście także - czy przede wszystkim - te zwiazane z Kościotem, jest silniejsza od Polski permi-

32 Sondaż telefoniczny pokazujący role Marszatka Pitsudskiego w historii, PBS, [online] http://www.pbsdga.pl/x.php?x=209/Jozef-Pilsudski-rocznica-smierci.html, 1 VI 2012.

33 Projekt ten wciąż jest dostępny na stronie internetowej Prawa i Sprawiedliwości (www.pis.org.pl).

34 W literaturze można znaleźć podział Kościoła w Polsce na toruński (związany z działalnością ojca Rydzyka) i łagiewnicki (związany z osobą Jana Pawła II, jego naukami i środowiskiem krakowskim). Tematyka ta została szerzej opisana m.in. przez Jarosława Gowina w książce Kościót po komunizmie (Kraków-Warszawa 1995).

35 Obrazy wyświetlane podczas jego trwania ukazywały, że to wysokiej jakości opieka zdrowotna i troska o rodzinę są podstawą rozumienia słowa „solidarność” (http://www.pis.org.pl/multimedia.php\#). 
sywizmu, Polski odrzucenia historii, Polski, która, powiedzmy sobie, często wręcz dystansuje sie od samego stowa "Polska”, od samej polskości $i^{36}$. Oprócz widocznego tutaj kultu postawy patriotycznej można dostrzec kolejną próbę przekonania odbiorców, że tylko PiS dba o interes narodowy i jest jedynym sprawiedliwym i jedynym posiadającym taką moc, która pozwoli go urzeczywistnić.

Mit IV Rzeczpospolitej stanowił aglomerat różnych nakładających się mitów, co jest zjawiskiem charakterystycznym dla współczesnego mitu politycznego. Można się w nim dopatrzyć mitu współczesnego herosa i mitu ziemi obiecanej. Jako herosi zostali przedstawieni bracia Kaczyńscy, co było możliwe dzięki podkreśleniu ich nieodzownej roli w kształtowaniu „Solidarności”. Częste wykorzystywanie walki opozycyjnej i dziedzictwa ideologii ruchu stanowiło element kampanii partii. Jarosław Kaczyński na jednym z wieców poparcia dla rządu przekonywał, że my jesteśmy tu, gdzie wtedy, oni tam, gdzie stato ZOMO. Stawiając polityczną opozycję po stronie ZOMO, ówczesny premier rządu po raz kolejny posłużył się mitotwórczą rolą słowa, które w wyobrażeniu Polaków jest równoznaczne tylko z jednym - z wrogiem. Ponadto można zauważyć, że w ten sposób potraktował siebie i swoją partię jako jedynych godnych uznania budowniczych wolnej Polski ${ }^{37}$.

\section{PODSUMOWANIE}

Przykład Polski pokazuje, jak nietrafna jest diagnoza, że wraz z postępem i rozwojem cywilizacji mity polityczne będą zanikać. Mit okrągłego stołu przeniknął do społeczeństwa, ukazując obrady jako wielki, unikatowy na skalę światową sukces bądź podstępną zdradę ojczyzny. Mimo dostępu do literatury historycznej czy też wydanych transkrypcji rozmów, mit ten pozostał wciąż żywy. Reorientacja polityki ZSRR wobec państw Europy Środkowo-Wschodniej, rozkład wewnętrzny samego aparatu władzy komunistycznej w Polsce, działalność opozycji oraz radykalnie pogarszające się nastroje społeczeństwie należą do głównych powodów rozpoczęcia transformacji ustrojowej w Polsce. Mimo że już przed oficjalnymi obradami okrągłego stołu strona opozycyjna prowadziła negocjacje z aparatem komunistycznym, a władze PRL zapoczątkowały procesy liberalizacyjne w gospodarce, mit o tym, że transformacja ustrojowa była wynikiem dwumiesięcznych obrad, został utrwalony.

Ponadto mit ten jest wykorzystywany współcześnie, by przez przedstawienie negocjacji jako aktu zdrady narodu i ojczyzny zaprezentować opinii publicznej proste rozwiązanie późniejszych niepowodzeń. Z kolei w oparciu o te niepowodzenia mógł zaistnieć mit IV Rzeczpospolitej, który doprowadził do ostatecznego celu politycznego każdego ugrupowania, jakim jest zdobycie władzy. Nie doszłoby do tego, gdyby nie używanie symboli Józefa Piłsudskiego i „Solidarności”. Sukces nie byłby tak łatwo osiągalny, gdyby nie przekonanie opinii publicznej przez użycie mitu nowego państwa, ukazanie heroicznej mocy

PiS i PO gotowe na wybory, „Nasz Dziennik” 27 VIII 2007, s. 5.

37 Po tym wystąpieniu oficjalny list do premiera z żądaniem przeprosin wystosowali m.in.: Lech Wałęsa, Bogdan Lis, Henryka Krzywonos-Strycharska. 
działaczy partyjnych oraz proste i czytelne przypisanie sobie rangi jedynych sprawiedliwych. Wystarczyło to, by przyciągnąć do siebie niezdecydowany elektorat, a przez to doprowadzić do zwycięstwa Prawa i Sprawiedliwości w wyborach parlamentarnych z 2005 r. i zdobycia prezydentury przez Lecha Kaczyńskiego w tym samym okresie. Innym istotnym czynnikiem wydaje się także kultura polityczna społeczeństwa polskiego. Lata komunizmu i młodość naszej demokracji niewątpliwie powodują, że postawy charakterystyczne dla kultury poddańczej czy zaściankowej są wciąż obecne.

Niewiedza oraz brak świadomości czy zainteresowania areną polityczną sprzyjają wykorzystywaniu w polityce treści bogatych w komponent emocjonalny. Mimo irracjonalności, w szybki i prosty sposób pozwalają one zapanować nad społeczeństwem, pozwalając sprytnemu homo faber na stworzenie kolejnego mitu; wyjście poza niego staje się już, w opinii Bruno Schulza, niemożliwe. Stwierdzenie to jest trafne zwłaszcza w przypadku współczesnych mitów politycznych, dla których rozrysowanie linii podziału pomiędzy elementem magicznym i kłamliwym a zawierającym znamiona prawdy historycznej i politycznej staje się niewykonalne.

\section{BIBLIOGRAFIA}

\section{Publikacje książkowe:}

\section{Literatura pomocnicza:}

- monografie i opracowania:

Bal-Nowak M., Mit jako forma symboliczna w ujęciu Ernsta A. Cassirera, Kraków 1996.

Biernat T., Mit polityczny, Warszawa 1989.

Cassirer E., The Myth of the State, Westport 1983.

Dudek A., Historia polityczna Polski 1989-2005, Kraków 2007.

Eliade M., Aspekty mity, przeł. P. Mrówczyński, Warszawa 1998.

Huntington S., Trzecia fala demokratyzacji, przeł. A. Dziurdzik, Warszawa 1995.

Kołakowski L., The Presence of Myth, transl. A. Czerniawski, Chicago-London 1989.

Kowalski K., Europa - mity, modele, symbole, Kraków 2002.

Szałamacha P., IV Rzeczpospolita - pierwsza odstona. Dlaczego się nie udato, co trzeba zrobic, Poznań 2009.

Schulz B., Opowiadania; Wybór esejów i listów, oprac. J. Jarzębski, Wrocław 1989.

- artykuły w pracach zbiorowych:

Chodak J., Zostaty „zrobione” czy nadeszty? Transformacje polityczne roku 1989 w Europie Wschodniej w perspektywie teorii rewolucji, [w:] Okragly Stót - dwadzieścia lat później. Zbiór studiów, red. W. Polak i in., Toruń 2009.

Frybes M., Michel P., Po komunizmie. O mitach w Polsce wspótczesnej. Wstę, [w:] Wielka transformacja. Zmiany ustroju w Polsce po 1989, red. I. Krzemiński, Warszawa 2011.

Pawełczyk P., Piontek D., Mity i stereotypy w socjotechnikach wyborczych, [w:] W kręgu mitów i stereotypów, red. K. Borowczyk, P. Pawełczyk, Poznań-Torun 1993.

Sanecka J., Trembicka K., Okragty Stót w Polsce - Mity i stereotypy w dwadzieścia lat później, [w] Okragty Stót - dwadzieścia lat później. Zbiór studiów, red. W. Polak i in., Toruń 2009. 
- artykuły prasowe:

Kubnik A., Olejnik M., Rachunek win, „Gazeta Wyborcza” 3 II 2001.

PiS i PO gotowe na wybory, „Nasz Dziennik” 27 VIII 2007.

\section{Publikacje elektroniczne:}

\section{Literatura pomocnicza:}

\section{- artykuły prasowe:}

Górski A., Jaka IV Rzeczpospolita?, Wywiad przeprowadzony na terenie Parafii Rzymsko-Katolickiej Narodzenia NMP na Płudach, 5 VII 2006, [online] http://www.pis.org.pl/article.php?id=4569.

Konferencja: Okragty Stót to fenomen w skali światowej, PAP, 6 II 2009, [online] http://www. naukawpolsce.pap.pl/aktualnosci/news,358804,konferencja-okragly-stol-to-fenomen-w-skali-swiatowej.html.

Korwin-Mikke J., Okragty Stót, „Najwyższy Czas!”, 1 I 2005, [online] http://korwin-mikke.pl/ najwyzszy_czas/zobacz/bdquookragly_stolrdquo/240.

Pod brama stoczni. Jurczyk: Wszystko idzie źle, Gazeta.pl, 30 VIII 2010, [online] http://szczecin. gazeta.pl/szczecin/1,34939,8315367,Pod_brama_stoczni_Jurczyk_Wszystko_idzie_ zle.html.

Sondaż telefoniczny pokazujacy role Marszatka Pitsudskiego w historii, PBS, [online] http:// www.pbsdga.pl/x.php?x=209/Jozef-Pilsudski-rocznica-smierci.html.

Sygnaty dnia, „Program Pierwszy Polskiego Radia”, 10 VII 2007, [online] http://www.polskieradio.pl/jedynka/sygnalydnia/artykul10167.html.

Sygnaty dnia, „Program Pierwszy Polskiego Radia”, 3 IV 2007, [online] http://www.polskieradio.pl/jedynka/sygnalydnia/artykul9967.html.

To się $w$ pale nie mieścito, $w \dot{z}$ adnej pale, Interia.pl, 5 II 2009, [online] http://fakty.interia.pl/ raport/20-lat-okraglego-stolu/news/to-sie-w-pale-nie-miescilo-w-zadnej-pale, 1254878.

Tusk: Ofiary Katyniaczekają, by przemociktamstwo zmienićw pojednanie, Gazeta.pl Wiadomości, 7 IV 2010, [online] http://wiadomosci.gazeta.pl/wiadomosci/1,114873,7741000,Tusk

Ofiary_Katynia_czekaja_by_przemoc_i_klamstwo.html.

\section{Strony internetowe:}

http://www.pis.org.pl/multimedia.php

Joanna WŁODARCZYK, magister europeistyki Uniwersytetu Jagiellońskiego (2012) oraz magister politologii Uniwersytetu Pedagogicznego (2010). Uczestnik studiów podyplomowych z zakresu mechanizmów funkcjonowania strefy euro współfinansowanych przez Narodowy Bank Polski. Stypendystka programu praktyk oraz dwóch kursów intensywnych Erasmus, uczestniczka szkoły letniej CEEPUS oraz licznych zagranicznych konferencji. Interesuje się Europejską Polityką Sąsiedztwa, polityką rozwoju oraz polityką regionalną UE. 